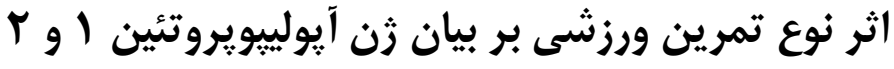 در بافت كبدى رت هاى نر نزاد ويستار
}

$$
\text { بهمن حسنوند "*. كبرى كرمى'، يعقوب مهرى الوار” }
$$

ا) كروه تربيت بدنى، دانشكده ادبيات، دانشكاه آزاد (سلاميc، ولحد غرم آباد، فرمم آباد، إيرانغ

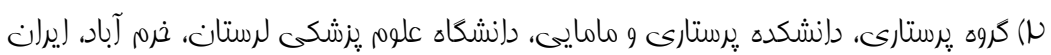

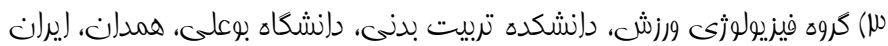

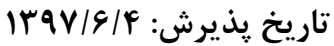

\author{
تاريخ دريافت: سو
}

\begin{abstract}
جكيده

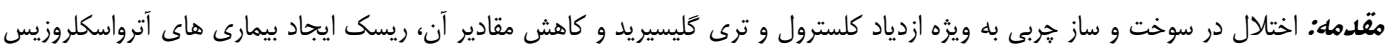

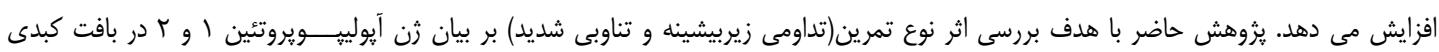

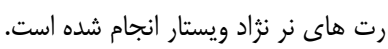

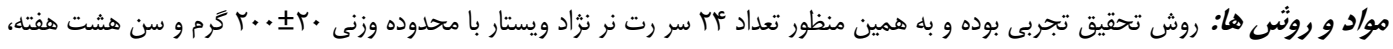

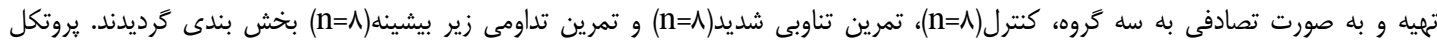

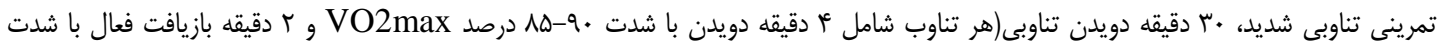

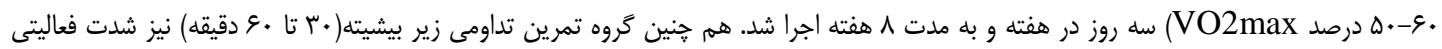

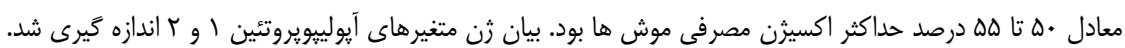

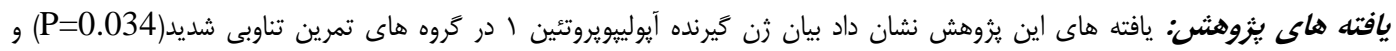

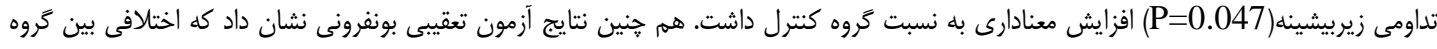

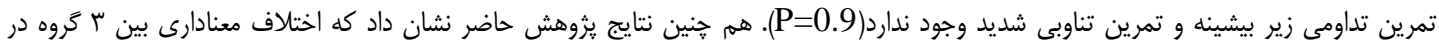

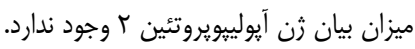

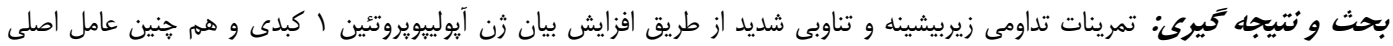

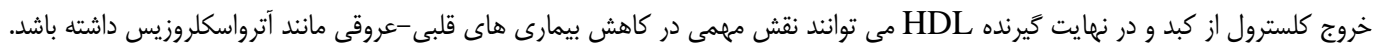

$$
\text { وازه هاى كليدى: تمرين استقامتى، تمرين تناوبى شديد، آيولييويروتئين او ب }
$$

* نويسنده مسئول: كروه تربيت بدنى، دانشكده ادبيات، دانشخاه آزاد اسلامى، واحد خرم آباد، خرم آباد، ايران Email:Hasanvand121@gmail.com

Copyright () 2019 Journal of Ilam University of Medical Science. This is an open-access article distributed under the terms of the Creative Commons Attribution international 4.0 International License (https://creativecommons.org/licenses/by-nc/4.0/) which permits copy and redistribute the material, in any medium or format, provided the original work is properly cited. 
I يكى از كليـــــــى ترين مـــــانيسم هاى محافظتى

HDL در مقابل آترواسكلروزيس است(ه).

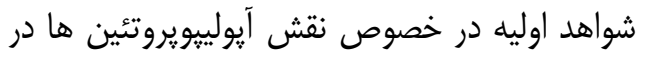

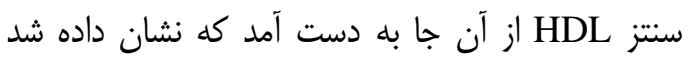

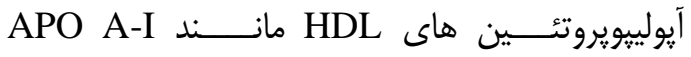

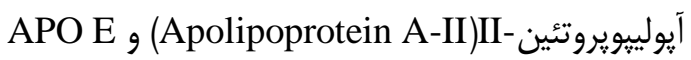
سبب دفع فسفولييبد و كلسترول از ماكروفازها و تشكيل

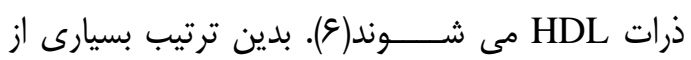
سلول ها مانند ماكروفازها و اكثر فيبروبلاست ها قادرند با آيولييويروتئين تعامل بيدا كرده و HDL هايى اشباع از كلسترول توليد كنند و اين در حالى است كه برخى از

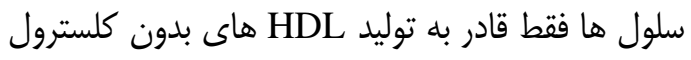

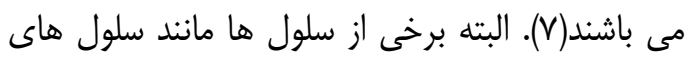

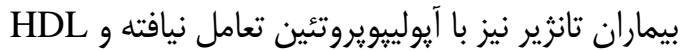

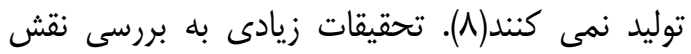

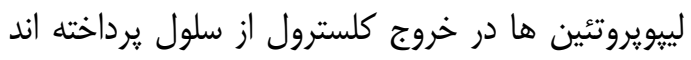
و مشخص شده است كه يذيرنده ترجيحى كلسترول و آنس فسفوليييد از يروتئين ناقل جعبه اى وابسته به آدنوزين

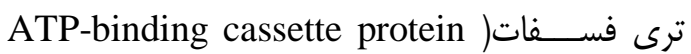
مى باشد كه آيولييويروتئين اصلى در APO A-I ،(A1 است. HDL A-I بيش از • V درصد يروتئين HDL و •" درصد توده HDL را تشكيل مى دهد (9). نشان داده شده كه نمونه هاى انسانى با فقدان APO و و نمونه هاى رت با فقدان A-I

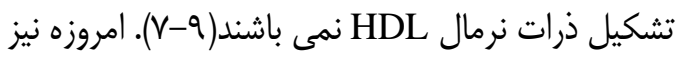
اكثر تحقيقات بر مسير ABCA1/APO A-I در دفع

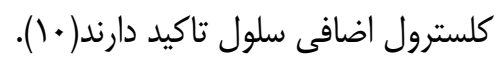

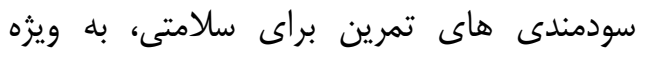

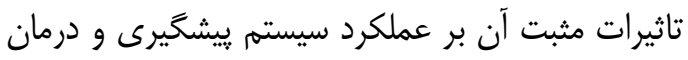
برخى بيمارى ها مانند آرترواسكلروزيس بيمارى هائ هاى بئي

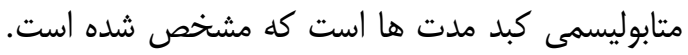

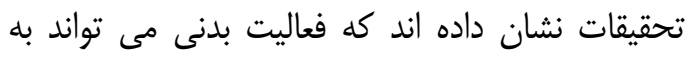

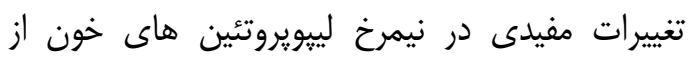

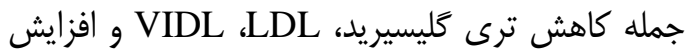

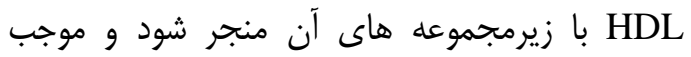

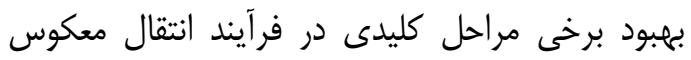
كلسترول مانند افزايش مقدار و تركيب HDL، افزايـش

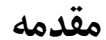

اختلال در سوخت و ساز جربى به ويزه ازدياد كلسترول و ترى كليسيريد و كاهش مقادير لييويروتين

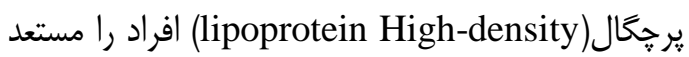
بيمارى هاى آترواسكلروزيس مى كند. از طرفى سبك زندكى غيرفعال ماشينى هم اين بيمارى ها را تشديد

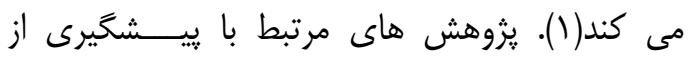

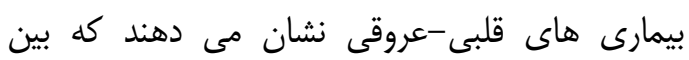
ازدياد HDL و مقدار رسوب هربى تروفى در عروق ارتباط معكوسى وجود دارد(T). افزايش در هر واحد

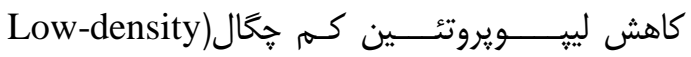

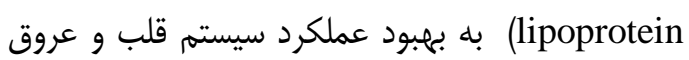

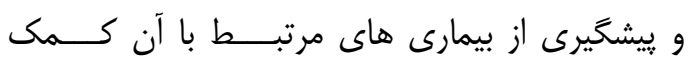

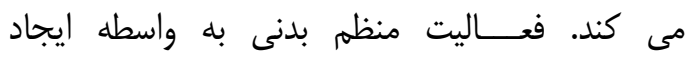

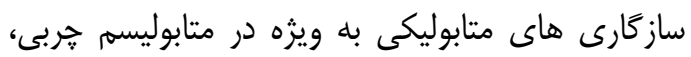

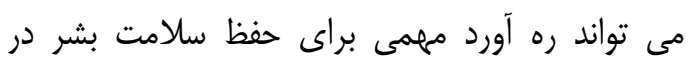
جوامع امروز باشد (1). نقش آنتى اكسيدانى و ضد التهابى دارد ولى HDL باور عمومى بر آن است كه HDL با انتقال معكوس أنى

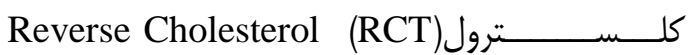
- در ييشخيرى از بيمارى هاى قلبى (Transport)

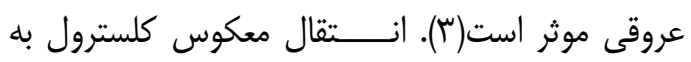

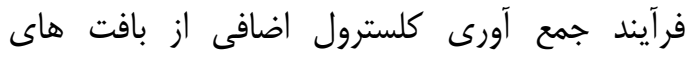

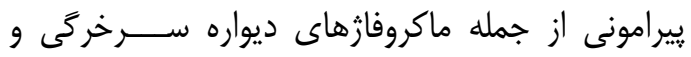

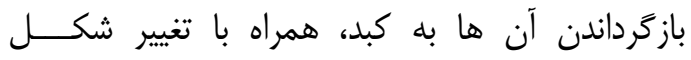

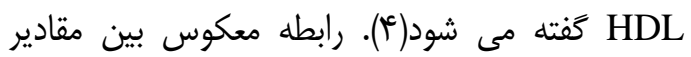
HDL

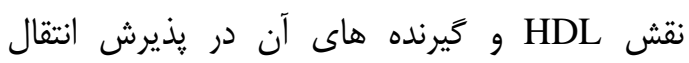
كــلسترول است. برداشت كلسترول هاى اضافى از

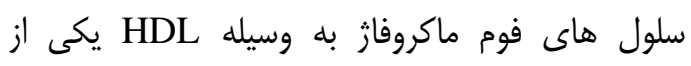
كليدى ترين مكانيسم هاى محافظتى فاكس

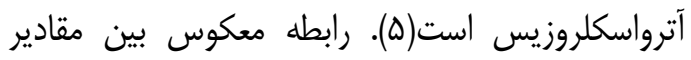

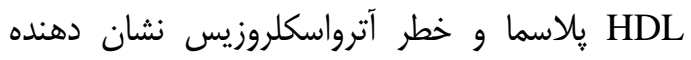

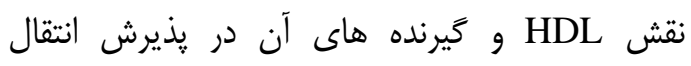
كلسترول است. برداشت كلســـترول هاى اضافى از سلول هاى فوم ماكروفاز به وسيله HDL و آل آيولييويروتئين هاى اساسى اش(-Apolipoprotein A 
براى يافتن راهبردهاى جديد براى ييشگيرى و بهبود

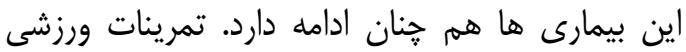

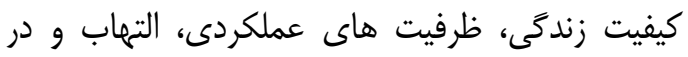

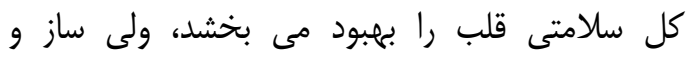
كارهاى درگير در اين رويدادها هنوز به طور كامل بهل ناشناخته اند. در سال هاى اخير، علاقه به تحقيق در دراين روائ حوزه زنتيك و ياسخ بدن به فعاليت ورزشى افزايش يافته است و شواهدى وجود دارد كه نشان مي ونى دهند سازكارى هاى فيزيولوزيكى ناشى از فعاليت هاى

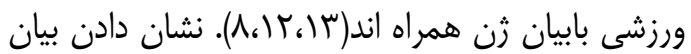
يا عدم بيان زن هاى مرتبط با انتقال معكوس ناشى از

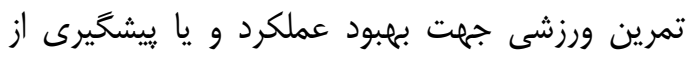

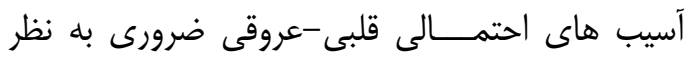

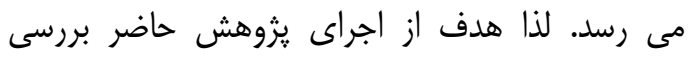
نقش نوع تمرين ورزشى(تداومى زير بيشينه و تناوبى

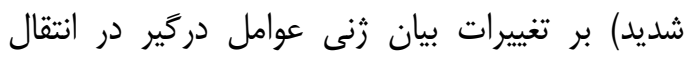
معكوس كلسترول مى باشد.

\section{مواد و روش ها}

روش يزوهش حاضر از نظر روش اجرا تجربى و از نظر هدف يك مطالعه كاربردى مى باشد. اين مطالعه تجربى در كميته اخلاق حيوانات علوم يزشكى ايران إنى

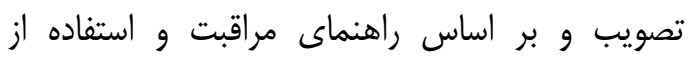

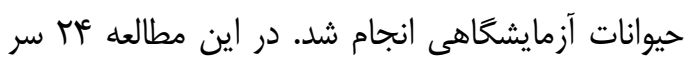

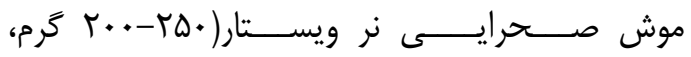
خريدارى شده از دانشعاه علوم يزشكى ايران) مورد ورد

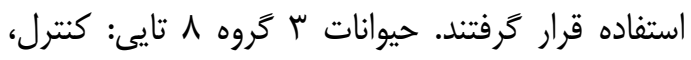
تمرين تناوبى شديد و تمرين تداومى زير بيشينه در حرات

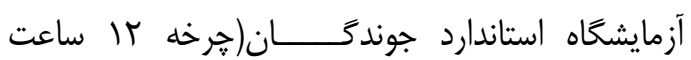

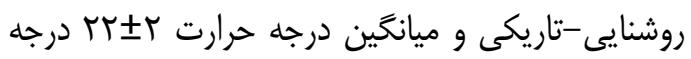

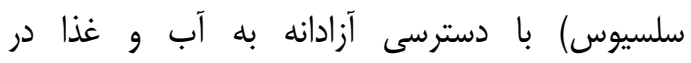

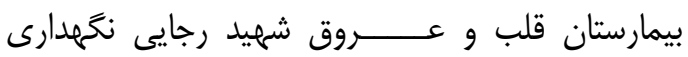

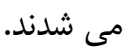

كليه نمونه ها از مركز تكثير و يرورش حيوانات آزمايشگاهى انستيتو ياستور ايران به طور سالم تحويل

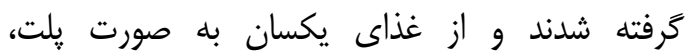

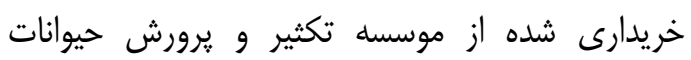

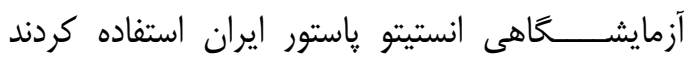

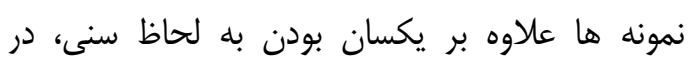

خروج كلسترول از سلول، افزايش تشكيل و انـــــازه Apo A-I افزايش فعاليت آنزيم لسيتين كلسترول اسيل ترانسفراز (Lecithin-Cholesterol Acyl Transferase) شود(V،N). در رابطه با ارتباط فعاليت ورزشى و انتقال معكوس كلسترول تحقيقات اندكى انجام شده است.

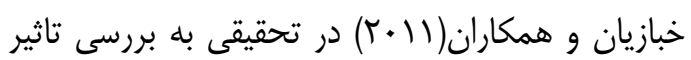

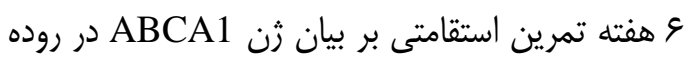

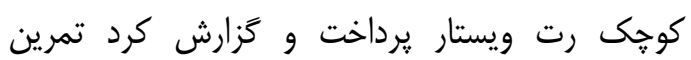

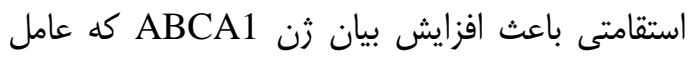
كليدى در خروج كلسترول از سلول است در إن رود روده

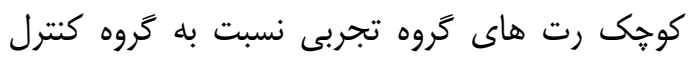
شده است(1) (1).

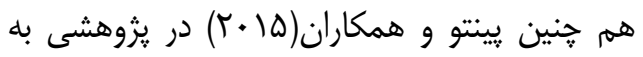

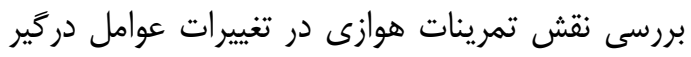
در بيان زن انتقال معكوس كلسترول در ماكروفازها

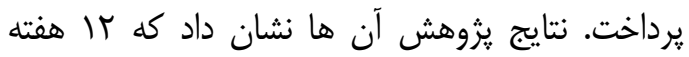

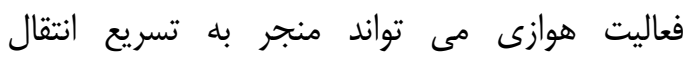

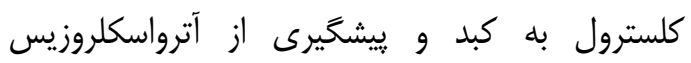

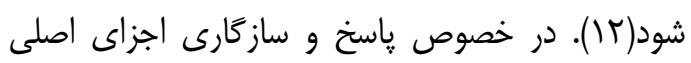

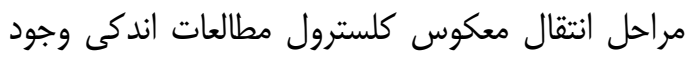
دارد؛ و يزوهش هاى انجام شده در كشورمان بيشتر به

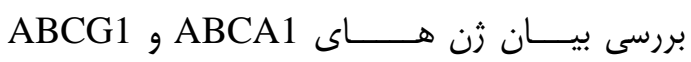

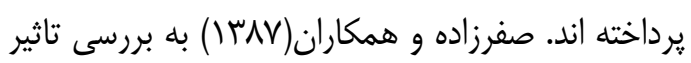

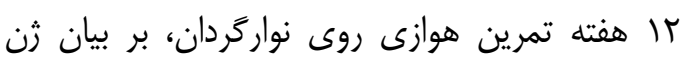

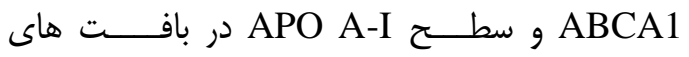
(كبد، عضله دوقلو و قلب) رت هاى ويستار يرداختند و

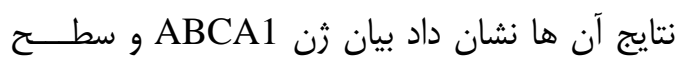
APO A- I

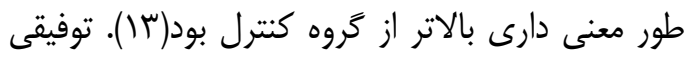

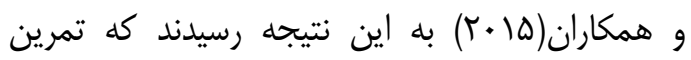

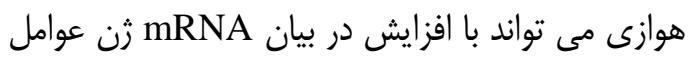

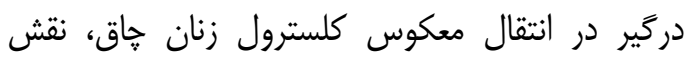

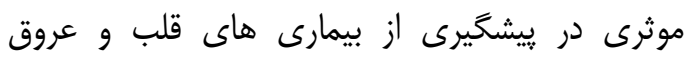

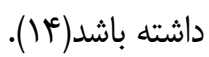
با وجود ييشرفت در زمينه داروها و مداخله هاى

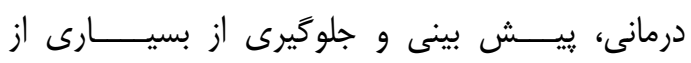

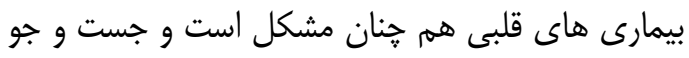




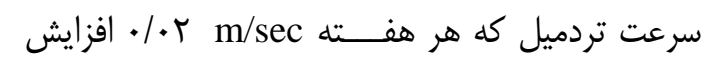

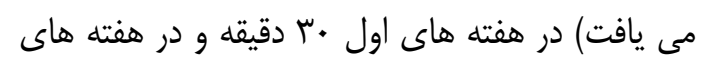

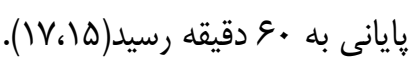

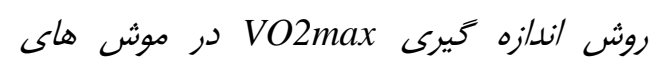

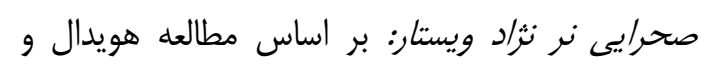

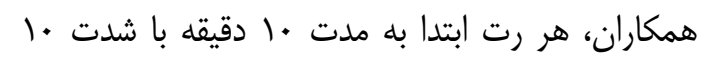

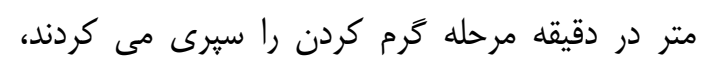
سيس آزمون فزاينده ورزشى آغاز شد، هر دو دو دقيقه مئه

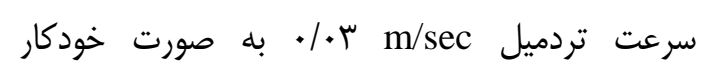

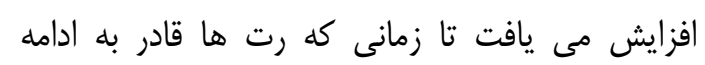

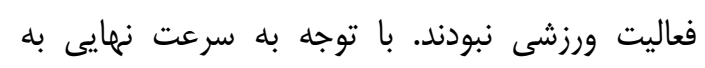
دست آمده در انتهاى آزمون بيشينه و بر اساس مطالعه بـ نواليه

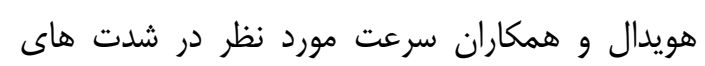
برنامه تمرينى به دست آمد(ه)، (1)).

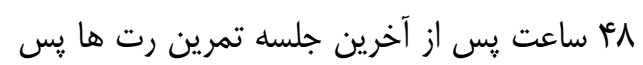

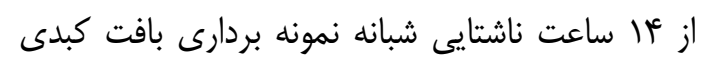

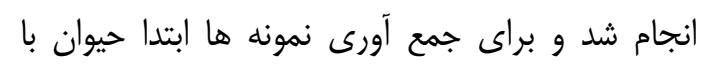

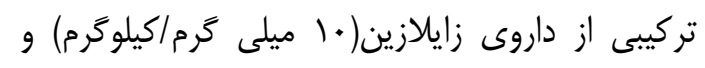

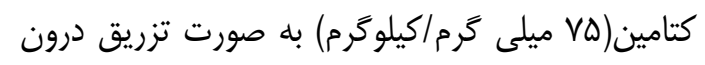

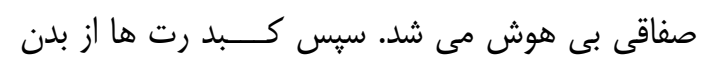

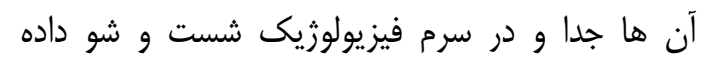

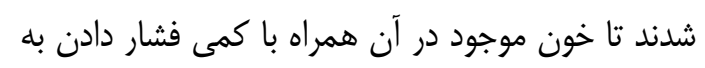

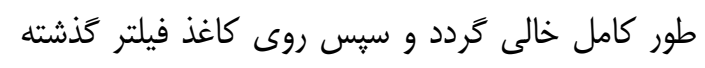

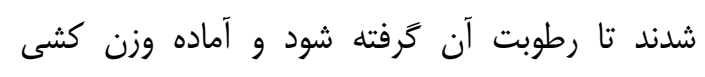

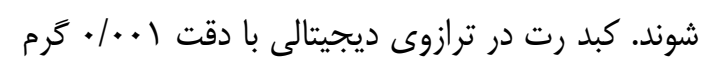

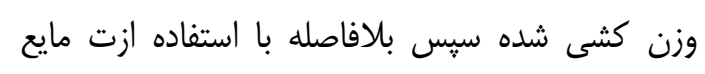

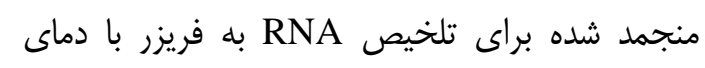
^- منتقل شدند. در اين مطالعه به منظور بررسى تغييرات بيان ثن من من متغيير وابسته تحقيق از تكنيك وRT-PCR استفاده شد. بدين منظور ابتدا RNA سلول ها استخراج شد و و تحنيك

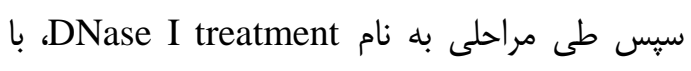
تيمار شد. در اين روش در صورت وجود نم

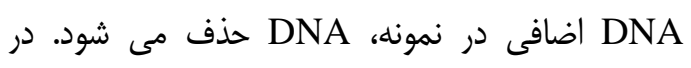

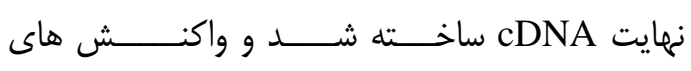
qRT- PCR

استخراج RNA از بافت نمونه با استفاده از (كيت Qiagen Qiazol
شروع يروتكل به لحاظ وزنى نيز همكن سازى شدند

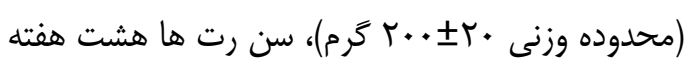
بود و در شرايط يكسان و تحت دما، رطوبت، تهويه و קرخه روشنايى تاريكى مطلوب براى نكمهدارى حيوانات آزمايشخاهى نتخهدارى شدند. آشناسازى رت ها با يروتكل ورزشى تناوبى شديد شيدي و

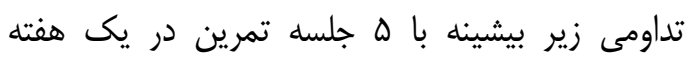

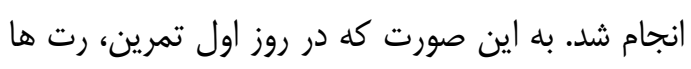

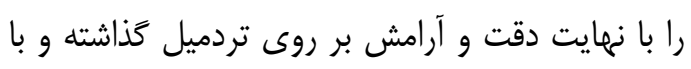

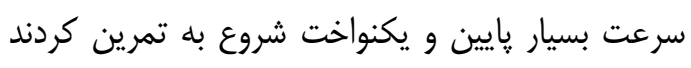

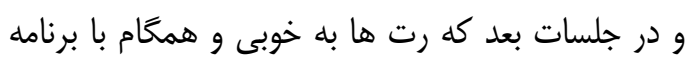

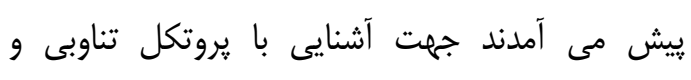

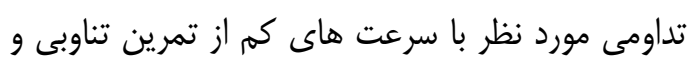

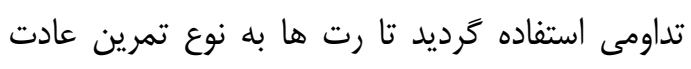

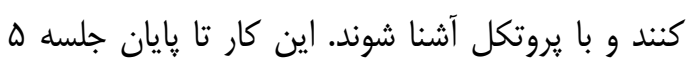

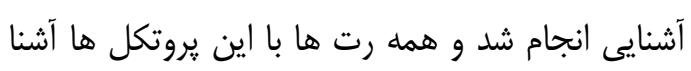

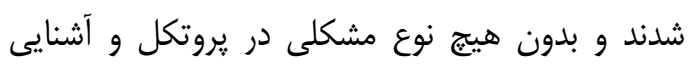

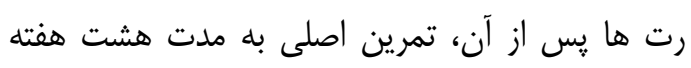
شروع و به يايان رسيد. تمرين وززشى و روش اجراى آزمون وززشى: برنامه تمرينى روى تردميل طراحى شده ويزه حيوان(ساخت

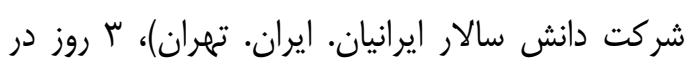

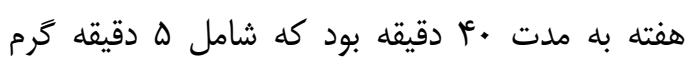

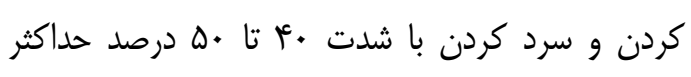

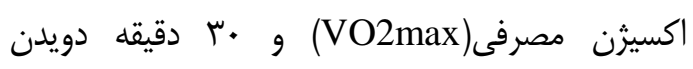

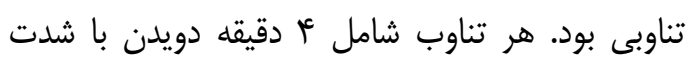

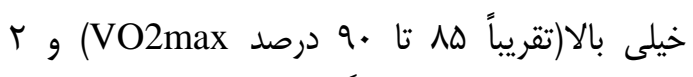

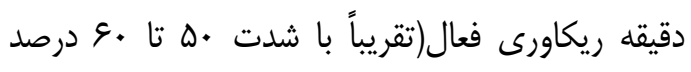

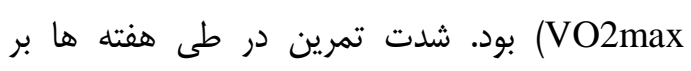

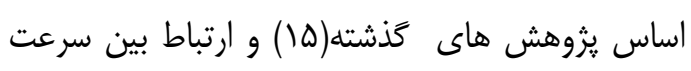

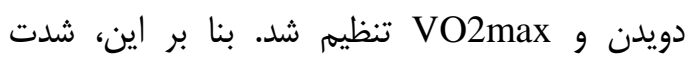

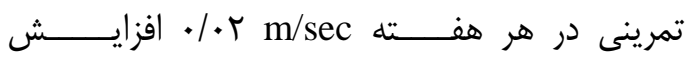

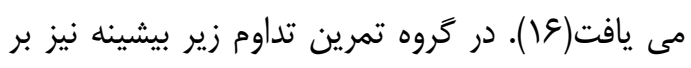

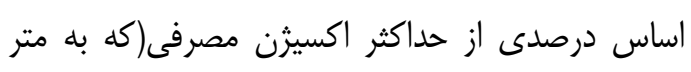

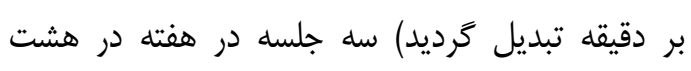

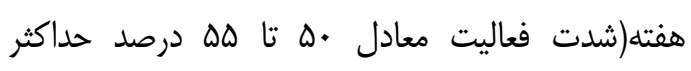

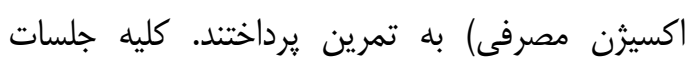
تمرين ساعت ^ تا سا انجام شد. زمان تمرين(علاوه بر بر بردين 
ميكروليتر dNTP و ا ميكروليتر RNasin اضافه شد تا حجم نهايى به 19 ميكروليتر برسد. محلول واكنش به مدت ه دقيقه در VV درجه سانتى گراد انكوبه شد.

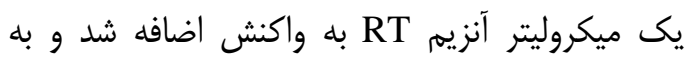
مدت ا ساعت در بع درجه سانتى گراد انكوبه شد. براى متوقف كردن واكنش، ميكرو تيوب به مدت مدات دقيقه در دماى •V درجه سانتى گراد قرار داده شد.

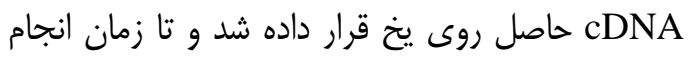
واكنش PCR در فريزر •r- درجـــه سانتى كراد

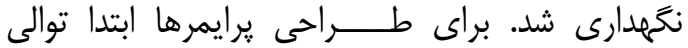

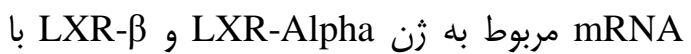
استفاده از سايت NCBI استخراج شد. برايمرها توسط

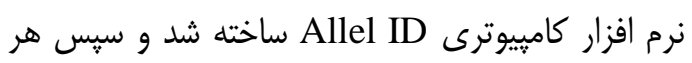
يرايمر توسط نرم افزار BLAST جهت اطمينان از يكتا بودن محل جفت شدن يرايمرها مورد ارزيابى قرار

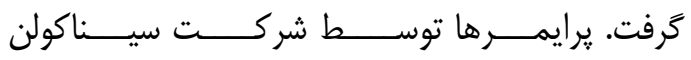

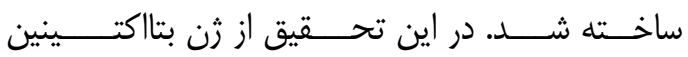
به عـــنوان كـــتنتل داخلى استفاده شد(جدول شماره

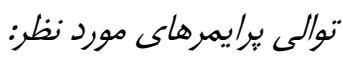

سازنده استخراج شد. به منظور از بين بردن احتمالى

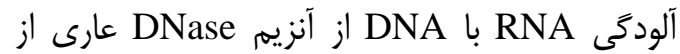
RNase RNA استخراج شده تعيين شد. بدين ترتيب به ازاى بلاي يك ميكروگرم RNA استخراج شده يك ميكروليتر Fermentase, 1 ( 1 1)DNase x 10 اضافه شد و حجم محلول با آب تيمار شده با مجان

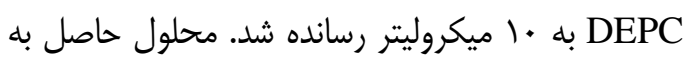
مدت ها دقيقه در WV درجه سانتى گراد انكوبه شد، سبِ به مدت ها دقيقه در هاء درجه سانتى گراد قرار داده شد تا آنزيم غيرفعال شود. غلظت RNA مله به روش

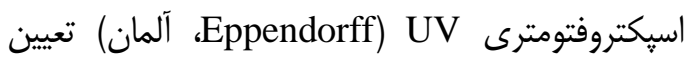
شد. جهت ساخت CDNA به r/ •--1 ميكروكرم RNA استخراج شده ا ميكرو ليتر Oligo dt اضافه شد. حجم نهايى اين مرحله بايد r| ميكروليتر باشد. بدين ترتيب

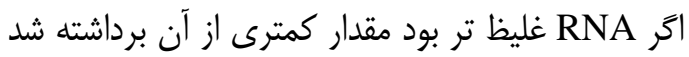

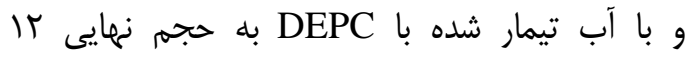
ميكروليتر رسانده شد. واكنش به مدت ه دقيقه در •Vدرجه سانتى گراد قرار داده شد و سيس بلافاصله درون

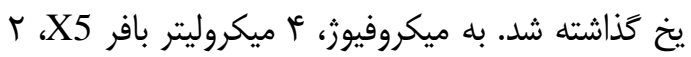

جدول شماره ا. توالى يرايمرهاى مورد نظر

\begin{tabular}{ccr}
\hline \multicolumn{2}{c}{ Name } & Seq. (5-3) \\
\hline ApoA1 زे & Rat -ApoA1-F: & 5'- CTGACAGGTTGCCAAGC -3' \\
& Rat -ApoA1-R: & 5'- CAGGAGATTCAGGTTCAGC -3' \\
ApoA2 & Rat -ApoA2-F: & 5'- GTCACCATCTGTAGCCT -3' \\
& Rat ApoA2-R: & 5'- GCCTTCTCCATCAAATCCT -3' \\
\hline
\end{tabular}

استاندارد اختصاصى هر زن(سرى هاى رقيق شده Delting رسم ترديد. نمودار نيز جهت بررسى (DNA صحت واكنش هاى PCR انجام شده به صورت اختصاصى براى هر زن و در هر بار از واكنش به همراه

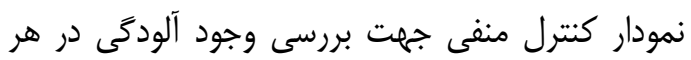

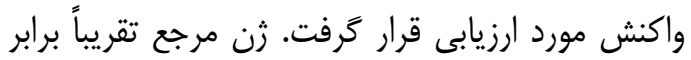

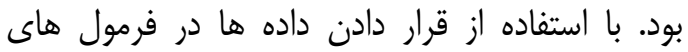

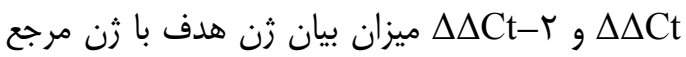
نرمال سازى شد. تجزيه و تحليل داده ها: از آمـــار توصيفى براى داى دادي دسته بندى داده هاى خام و توصيف داده ها استفاده
هC هر واكنش PCR master mix با استفاده از در SYBR Green و (Applied Biosystems دستخاه (Applied Biosystems, Sequence) طبق يروتكل شركت سازنده انجام گرفت. • ع سيكل براى

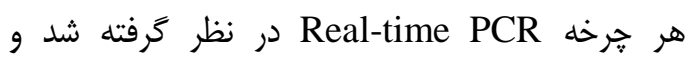
دماهاى هر سيكل شامل عز درجه سانتى گراد براى ها ثانيه، •و درجه سانتى گراد براى •ץ ثانيه تنظيم

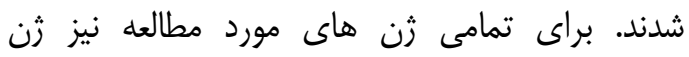

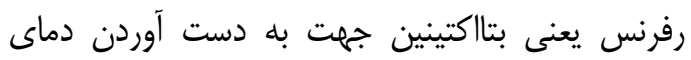
مناسب Anneling گراديان دمايى انجام گرديد. هم جنين جهت بررسى efficiency يرايمرها، منحنى 


\section{يافته هاى يزووهش}

بيان ثن: نتايج آزمون آناليز واريانس يك تيك راهه،

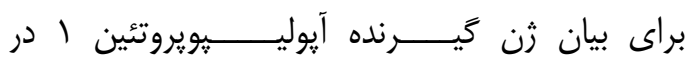

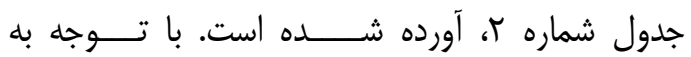

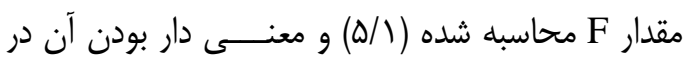

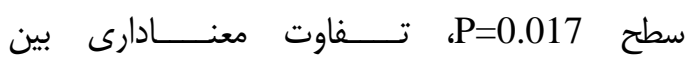

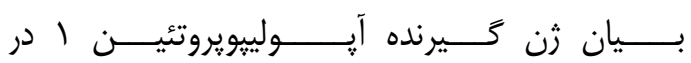

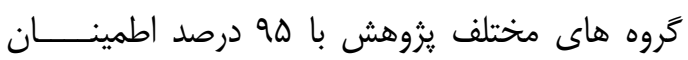
تاييد شد.
شد. آزمون شـــاييروَويلك براى بررسى نرمال بودن

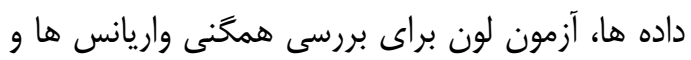

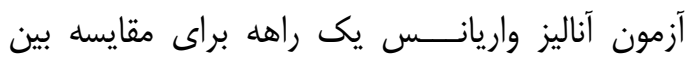

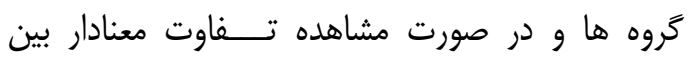
گروه ها از آزمون تعقيبى بونفرونى استفاده شد. سطح معنى دارى براى كليه آزمون هاى آمارى نظر گرفته شد. تجزيه و تحليل هاى آمارى با استفاده

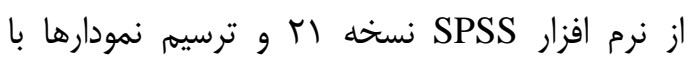

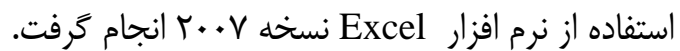

\begin{tabular}{|c|c|c|c|c|c|}
\hline P ارزش P & F ارزش F & درجه آزادى & مجذور ميانكَين & مقادير بيان زن(بيان نسبى) & ا كروه \\
\hline \multirow[t]{3}{*}{$* \cdot / \cdot 1 \mathrm{~V}$} & $\Delta / 1$ & $r$ & $I K / / \Lambda$ & $\Lambda / V \pm \Delta / \Lambda$ & كروه تمرين تناوبى شديد \\
\hline & & & & $N / \Delta \pm \Delta / \Lambda$ & كروه تداومى زيربيشينه \\
\hline & & & & $1 / V \pm r / 4$ & كروه كنترل \\
\hline
\end{tabular}

(P=0.034). هم جنين نتايج نشان داد كه اختافى بين

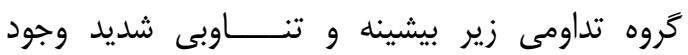

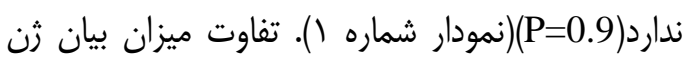

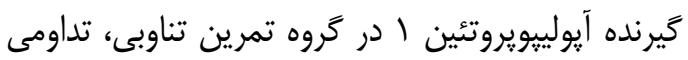

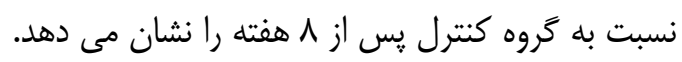

براى بررسى اختلاف مورد نظر از آزمون تعقيبى

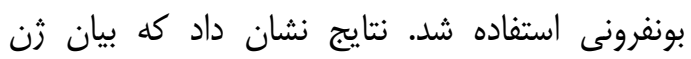

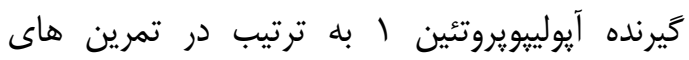

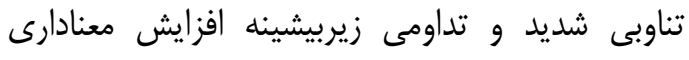

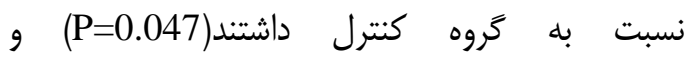

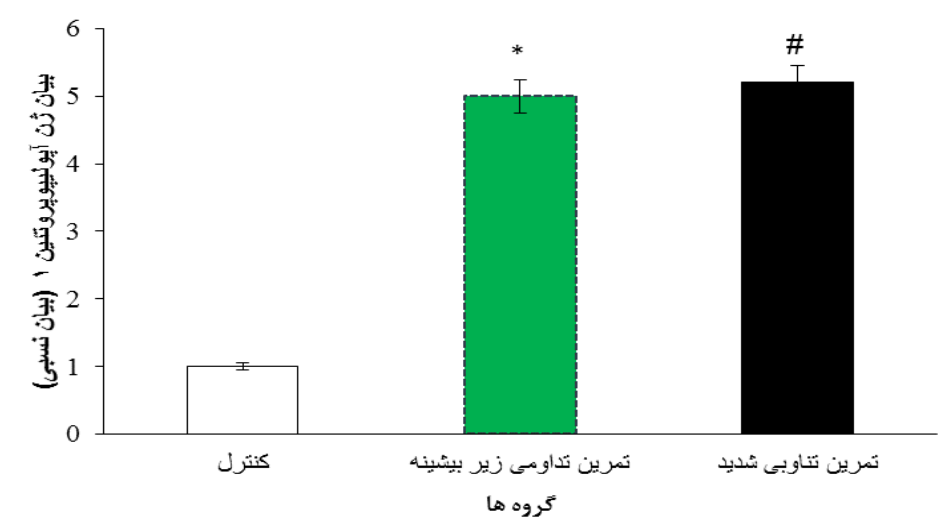

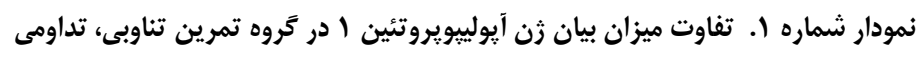

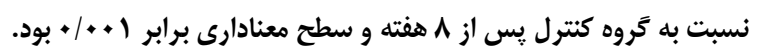

$\mathbf{P}<0.001$

$\mathbf{P}<0.001$

(ه//) و معنى دار بودن آن در سطح P=0.61)

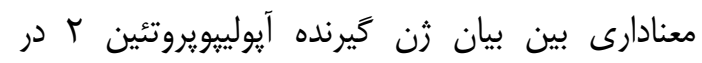
كروههاى مختلف يثوهش تاييد نشد(نمودار شماره r).
: * منترل-تداومى زير بيشينه

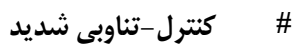



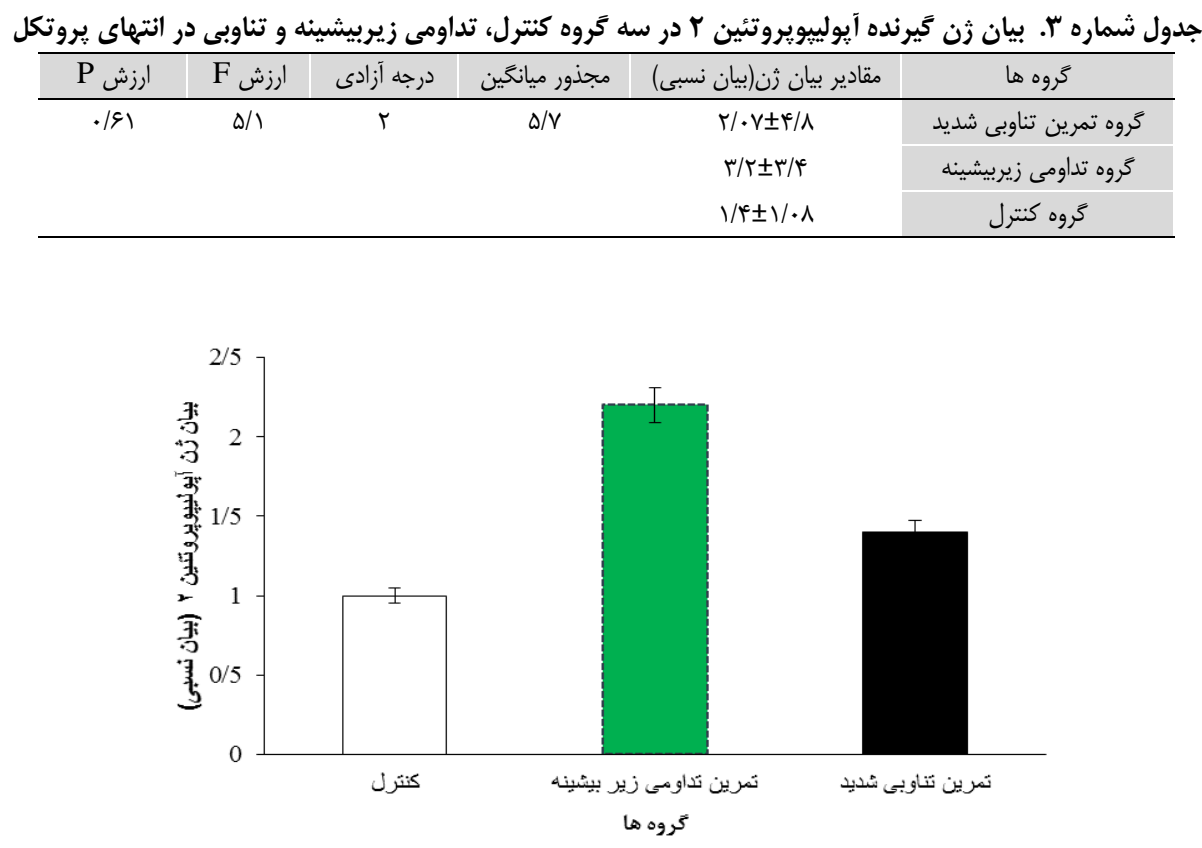

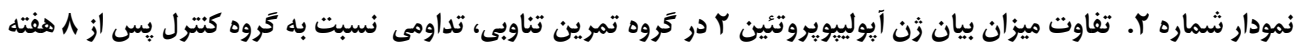

آيولييويروتئين نوع I با نتايج تحقيق صفرزاده و

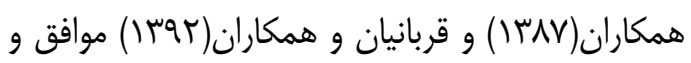

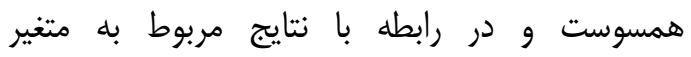

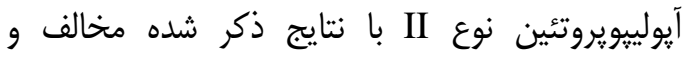

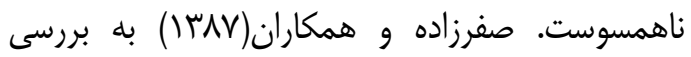
تاثير rا هفته تمرين هوازى روى نواركردان، بر بيان

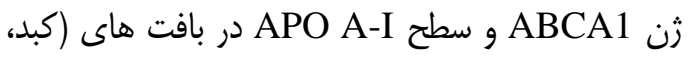
عضله دوقلو و قلب) موش ويستار يرداخته است. و نتايج

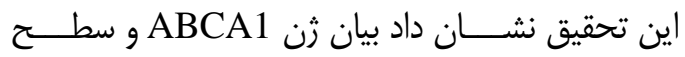
APO A-I

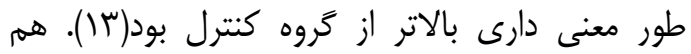

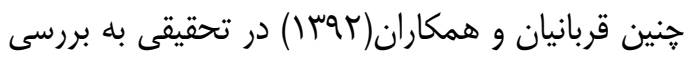
تاثير تمرين با طناب بر بيان زن ABCA1 ABCA

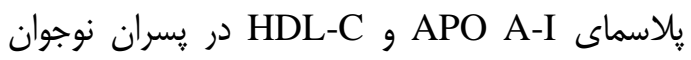
يرداختند و كزارش كردند كه تمرين با طناب باعث

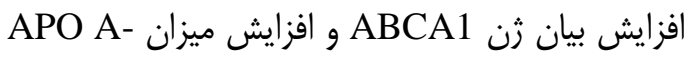

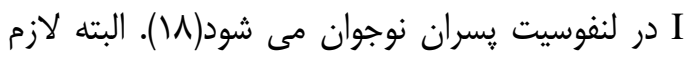

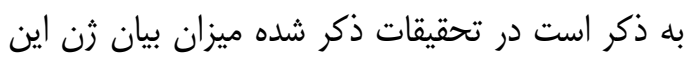

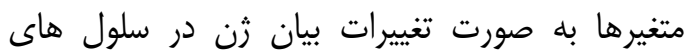
لنفوسيتى ارزيابى شده است.

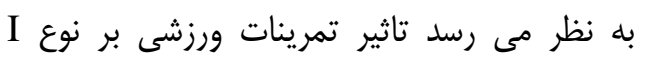

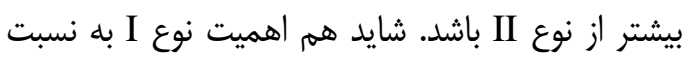

بحث و نتيجه كيرى

تزوهش حاضر نشان داد بين هشت هفته اجراى تمرين تناوبى شديد و تداومى زير بيشينه به به نسبت

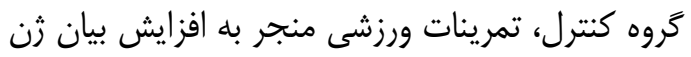

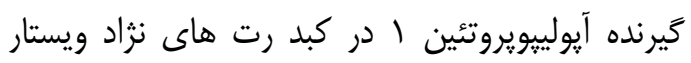

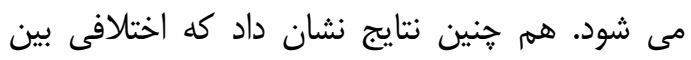

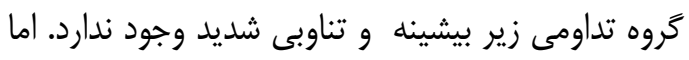

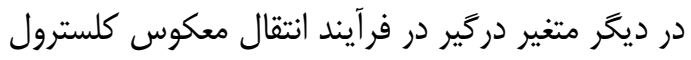

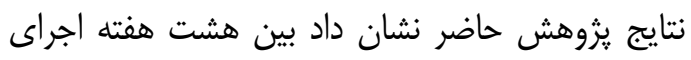

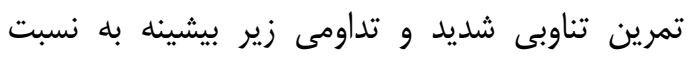

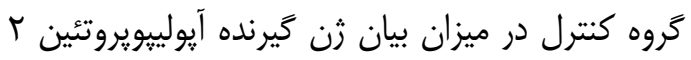

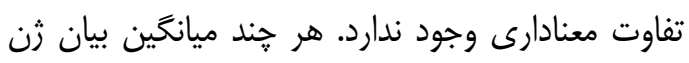

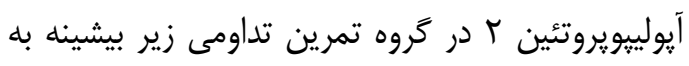
نسبت گروه تناوبى افزايش داشته است.

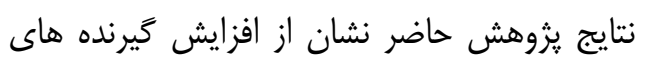

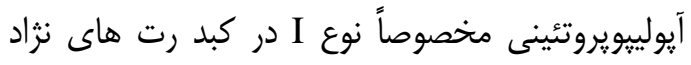

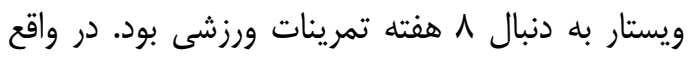

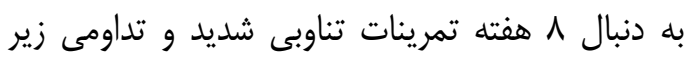

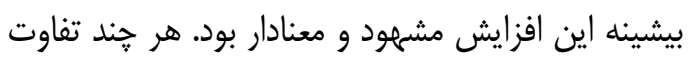
معنادارى بين نوع تمرين ورزشى بر اين متغيرها مشاهده نشد. اما در ميزان تغييرات آيولييويروتئين نوع تئن

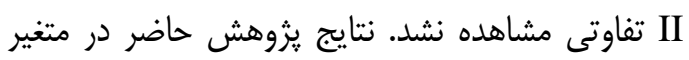


تمرينات ورزشى به افزايش بيان ثن عوامل دركير در بايوزنز ميتوكندريايى منجر مى شئ شود. احتمالاً دليل افزايش زياد $1 \alpha$ إيورنز ميتريابى (activated receptor $\gamma$ coactivator-1 $\alpha$ زياد كلسيه درون سلولى و تخليه شديد ATP در تمرينات ورزشى فعال سازى مسيرهاى ييام رسانى بالا

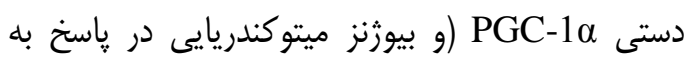
اجراى فعاليت ورزشى باشد كه هنوز به خوبى شناخته

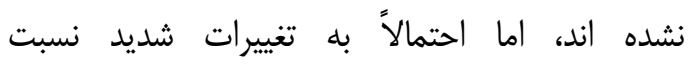
ATP:ADP/AMP شدن AMPK كه به دنبال فعاليت بدنى مى بـ باشد،

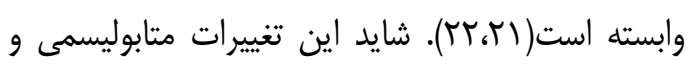

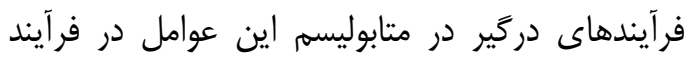

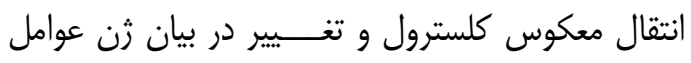
درگير در اين فرآيند موثر باشند كه نياز به تحقيقات بيشترى در آينده دارد.

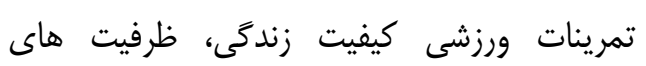

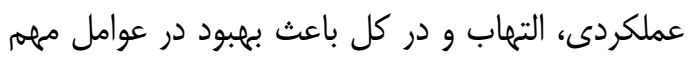

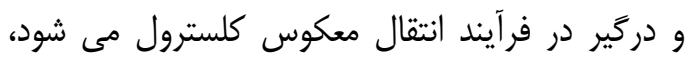
ولى ساز و كارهاى شركت كننده در اين رويدادها هنوز به طور كامل ناشناخته اند. در سال هاى اخير، علاقه به كاريه

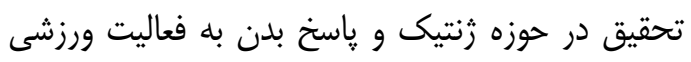

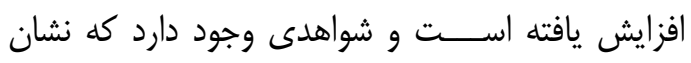

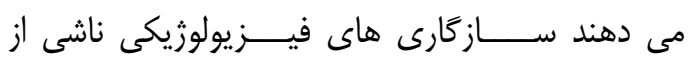

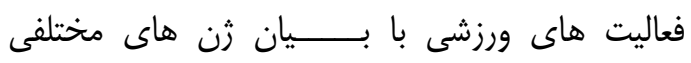

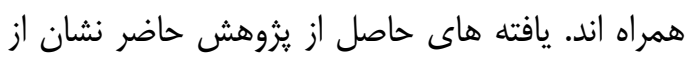

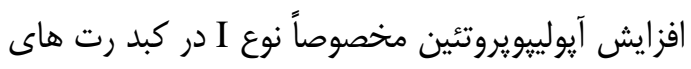

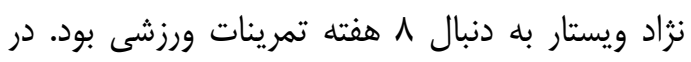

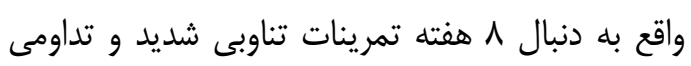

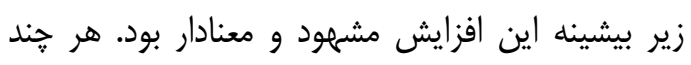
تفاوت معنادارى بين نوع تمرين ورزشى بر اين متغيرها

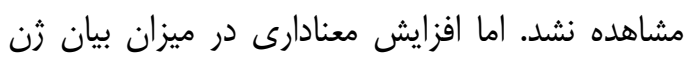
اين متغير به دنبال تمرين ورزشى كاملاً مشخص مئد بود.

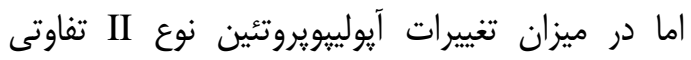

مشاهده نشد.

تمرينات ورزشى از طريق افزايش بيان ثن عوامل درگير در انتقال معكوس كلسترول در باف كبدى و هم

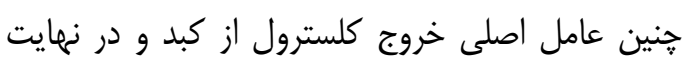

نوع در پاسخ دهى به تمرينات ورزشى و تاثير كذارى بر انتقال معكوس كلسترول بيشتر باشد. تمرينات ورزشى احتمالاً از طريق تغيير در سوخت و باشن

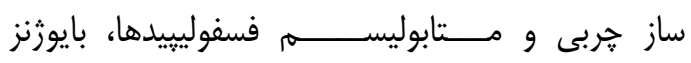
ميتوكندريايى و... بر انتقال معكوس كلسترول موثر

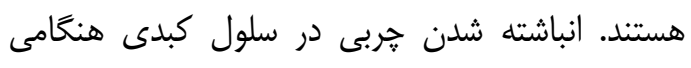

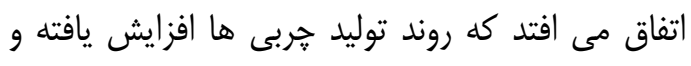

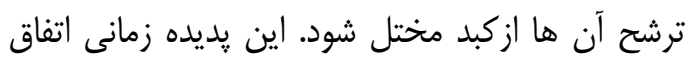

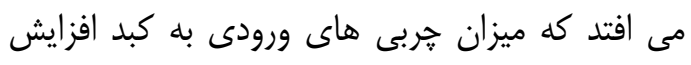

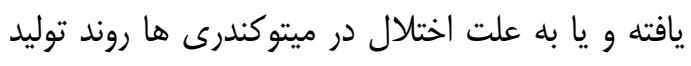

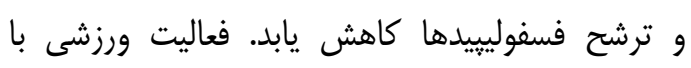

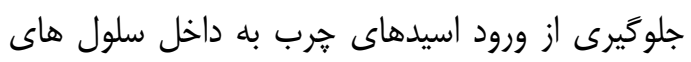

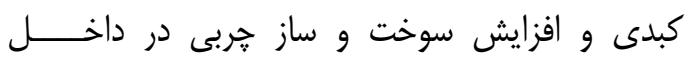

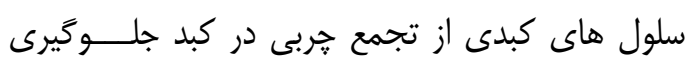

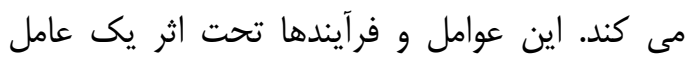

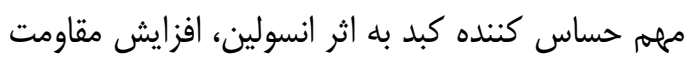
به انسولين و يا حتى بيوزنز ميتوكندريايى مى تواند باشد. اعتقاد بر اين است كه فعاليت ورزشى دئ در كبد مبد

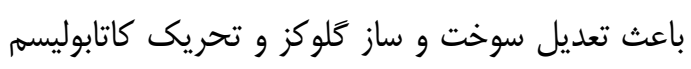

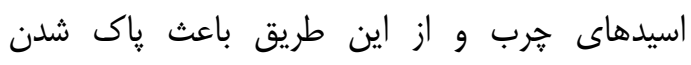

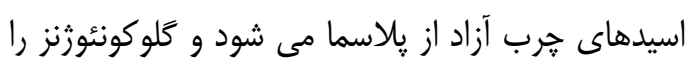

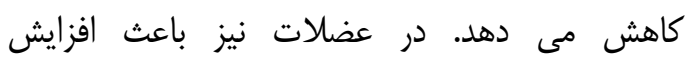

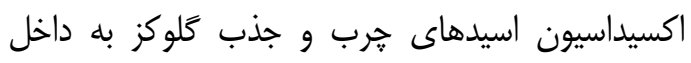

عضلات مخطط مى شود(19).

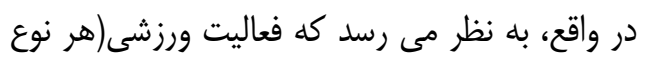

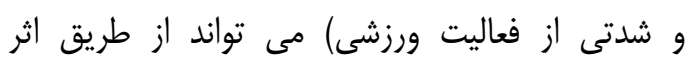

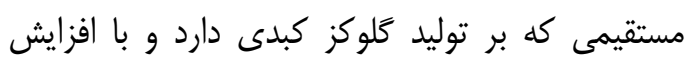

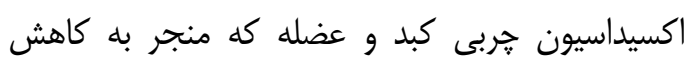
ذخاير جربى مى شود، حساسيت به انسولين را افزايش مى دهد و از طرف ديخر منجر به به بهبود روند انتقال

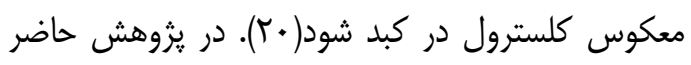
نيز نشان داده شد كه شدت تمرين(تناوبى شديد يا دئ

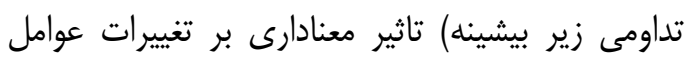
درگير در انتقال معوس كلسترول ندارد. فعاليت ورزشى با فعال سازى مسير يروتئين كيناز

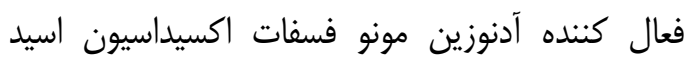
קرب در سلول هاى عضلانى را افزايش مى دهد (19). در واقع نتايج تحقيقات مختلف نشان داده است كه 


$$
\begin{aligned}
& \text { طولانى مدت و به دنبال تمرينات طولانى و شديد كه } \\
& \text { بيش از هند ماه طول مى كشد موجب بهبودى در } \\
& \text { شاخص هاى سلامتى و كاهش تربى هاى خئى خون و } \\
& \text { فرآيند انتقال معكوس كلسترول مى شود. } \\
& \text { كد اخلاق: (זسו, وهوسا (IR.SSRI.REC) } \\
& \text { سياسگزارى } \\
& \text { بدين وسيله از مديريت محترم تمامى مسئولين و }
\end{aligned}
$$

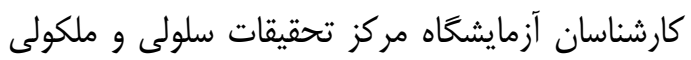

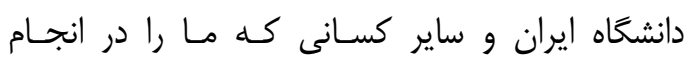

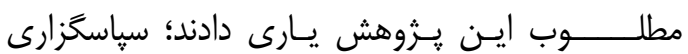

$$
\begin{aligned}
& \text { مى نماييم. }
\end{aligned}
$$

\section{References}

1.Gharipour M, Sadeghi M, Dianatkhah M, Nezafati P, Talaie M, Oveisgharan S, et al. Comparison between European and Iranian cutoff points of triglyceride/high-density lipoprotein cholesterol concentrations in predicting cardiovascular disease outcomes. J Clin Lipidol2016; 10:143-9. doi: 10.1093/eurheartj/ehr112.

2.Acharjee S, Boden WE, Hartigan PM, Teo KK, Maron DJ, Sedlis SP, et al. Low levels of high density lipoprotein cholesterol and increased risk of cardiovascular events in stable ischemic heart disease patients a post-hoc analysis from the Courage trial. J Am Coll Cardiol2013;621826-33. doi: 10.1016/j.jacc.2013.07.051

3.Oram JF. HDL apolipoproteins and ABCA1 partners in the removal of excess cellular cholesterol. Arterioscler Thromb Vascular Biol2003;23:720-7. doi:10.1161/01.ATV.0000054662.44688.9

A

4.Srivastava N. ATP binding cassette transporter A1-key roles in cellular lipid transport and atherosclerosis. Mole Cell Biochem 2002; 237:155-64. doi: 10.1097/MOL.0000000000000088.

5.Butcher LR, Thomas A, Backx K, Roberts A, Webb R, Morris K. Low intensity exercise exerts beneficial effects on plasma lipids via PPARgamma. Med Sci Sports Exe2008;40:1263-70. . doi: 10.1249/MSS.0b013e31816c091d.

6.Agarwala AP, Rodrigues A, Risman M, McCoy M, Trindade K, Qu L, et al. HDL phospholipid content and cholesterol efflux

$$
\begin{aligned}
& \text { گيرنده HDL مى تواند نقش مهـــــمى در كاهش } \\
& \text { بيمارى هاى قلبى-عروقى مانند آترواسكلروزيس داشته }
\end{aligned}
$$

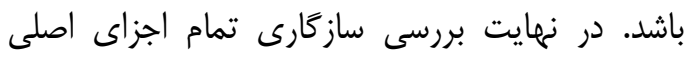

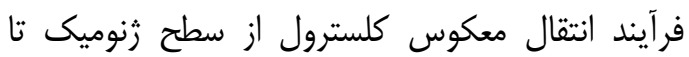

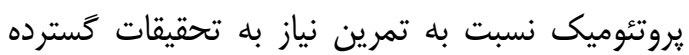

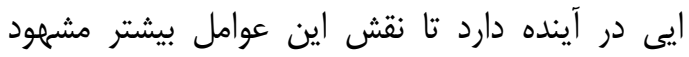

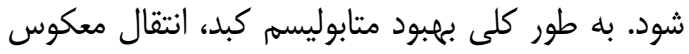

$$
\begin{aligned}
& \text { كلسترول و تغييرات كلسترولى به دنبال تمرين ورزشى دئ دئه } \\
& \text { به دليل نياز به مصرف انرزى و هزينه انرزى براى } \\
& \text { فعاليت ورزشى مى باشد. همين افزايش متغيرها در }
\end{aligned}
$$

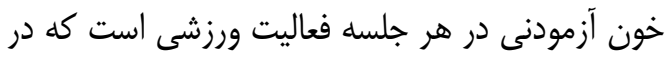

capacity are reduced in patients with very high HDL-C and coronary disease. Arterioscler Thrombosis Vas Biol2015;35:1515. doi: 10.1161/ATVBAHA.115.305504

7.Rashidlamir A, Saadatnia A, EbrahimiAtri A, Delphan M. Effect of Eight Weeks of Wrestling and Circuit Fitness Training on APO Lipoprotein AI and Lymphocyte ABCA1 Gene Expression in Well-Trained Wrestlers. International $\mathbf{J}$ Wrestling Sci 2011;1:48-53.

doi.org/10.1080/21615667.2011.10878931

8.Boden WE. High density lipoprotein cholesterol as an independent risk factor in cardiovascular disease: assessing the data from Framingham to the Veterans Affairs High-Density Lipoprotein Intervention Trial. Am J Cardiol 2000;86:19-22. doi.org/10.1016/S0002-9149(00)01464-8

9.Rosenson RS, Brewer Jr HB, Davidson WS, Fayad ZA, Fuster V, Goldstein J, et al. Cholesterol efflux and atheroprotection: advancing the concept of reverse cholesterol transport. Circulation 2012;125:1905. doi: 10.1161/CIRCULATIONAHA.111.066589 10.Rothblat GH, Phillips MC. High density lipoprotein heterogeneity and function in reverse cholesterol transport. Current Opin Lipidol 2010;21:229. doi: 10.1097/mol.0b013e328338472d

11.Khabazian BM, Niaki AG, Rahbarizadeh F, Kakhak AH, Noghabi MJ. The effect of 6 weeks of endurance training on the expression of hepatic ABCA1 in 
male wistar Rats. World J Sport Sci 2008;1:1-7.

12.Pinto PR, Rocco DD, Okuda LS, Machadolima A, Castilho G, Silva KS, et al. Aerobic exercise training enhances the in vivo cholesterol trafficking from macrophages to the liver independently of changes in the expression of genes involved in lipid flux in macrophages and aorta. Lip Health Dis2015;14:109. doi: 10.1186/s12944-015-0093-3

13.Safarzad A. Effect of 12 weeks aerobic training on treadmill on ABCA1 gene expression and APO A-I and HDL levels in tissues liver twin muscle and heart of wistar Mouse. Master Thesis Tarbiat Modares Uni Tehran. 2008

14.Tofighi A, Rahmani F, Qarakhanlou BJ, Babaei S. The effect of regular aerobic exercise on reverse cholesterol transport A1 and apo lipoprotein aI gene expression in inactive women. Iranian Red Crescent Med J2015;17:1-5.

doi:

10.5812/ircmj.17(4)2015.26321

15.Høydal MA, Wisloff U, Kemi OJ, Ellingsen Q. Running speed and maximal oxygen uptake in Rats and Mice practical implications for exercise training. European J Cardiovascular Preve Rehabil 2007; 14:753-60.doi:

10.1097/HJR.0b013e3281eacef1

16.Wisloff U, Stoylen A, Loennechen JP, Bruvold M, Rognmo O, Haram PM, et al. Superior cardiovascular effect of aerobic interval training versus moderate continuous training in heart failure patients: a randomized study. Circulation2007;115:3086-94. doi: 10.1161/circulationaha.106.675041
17.Ghorbanian B, Ravassi A, Kordi MR, Hedayati M. [The effects of rope training on lymphocyte ABCA1 expression, plasma ApoA-I and HDL-c in boy adolescents]. Int J Endocrinol Metab2013;11:76. (Persian) doi: $10.5812 /$ ijem. 8178

18.Canto C, Auwerx J. PGC-1alpha, SIRT1 and AMPK an energy sensing network that controls energy expenditure. Current Opin Lipidol 2009;20:98-100. doi:10.1097/MOL.0b013e328328d0a4 19.Gibala MJ, Mcgee SL, Garnham AP, Howlett KF, Snow RJ, Hargreaves M. Brief intense interval exercise activates AMPK and p38 MAPK signaling and increases the expression of PGC- $1 \alpha$ in human skeletal muscle. J Appl Physiol 2009; 106:929-34. doi: 10.1152/japplphysiol.90880.2008 20.Gibala MJ, Little JP, Essen M, Wilkin GP, Burgomaster KA, Safdar A, et al. Short term sprint interval versus traditional endurance training similar initial adaptations in human skeletal muscle and exercise performance. J Physiol 2006 15;575:901-11.

doi:

10.1113/jphysiol.2006.112094

21.Brousseau ME, Schaefer EJ, Wolfe ML, Bloedon LT, Digenio AG, Clark RW, et al. Effects of an inhibitor of cholesteryl ester transfer protein on HDL cholesterol. New England J Med 2004 ;350:1505-15. doi:10.1056/NEJMoa031766

22. Ghanbariniaki A, Khabazian BM, Hossainikakhak SA, Rahbarizadeh F, Hedayati M. Treadmill exercise enhances ABCA1 expression in Rat liver. Biochem Biophys Res Commun2007 ;361:841-6. doi: $\quad$ 10.1016/j.bbrc.2007.07.100 


\title{
The Effect of Training Type on Hepatic Gene expressions of Apolipoprotein A-I, and Apolipoprotein A-II among Male Wistar Rats
}

\author{
Hasanvand $B^{I^{*}}$, Karami $K^{2}$, Yaghoub $M^{3}$
}

(Received: December 4, 2017

Accepted: August 26, 2018)

\begin{abstract}
Introdaction: Lipid metabolism disorders, especially raised levels of cholesterol and triglycerides increases the risk of atherosclerosis. This study aimed to investigate the effect of training type including submaximal continuous and highintensity interval training on hepatic gene expression of Apolipoprotein A-I, and Apolipoprotein A-II in male Wistar rats.
\end{abstract}

Materials \& Methods: This experimental study conducted on 24 male Wistar rats with 8 weeks of age and weight range of 200-250 g. They were randomly assigned into three groups of control $(n=8)$, highintensity interval training $(\mathrm{n}=8)$, and continuous submaximal training $(\mathrm{n}=8)$. High-intensity interval training protocol included 30-min interval running 3 days a week for 8 weeks (each interval took 4 min with $85-90 \%$ of VO2max and 2-min active recovery with $50-60 \%$ of $\mathrm{VO} 2 \mathrm{max}$ ). In addition, submaximal continuous training group (30-60 min) was subjected to $50-55 \%$ intensity activity with maximum oxygen consumption. Finally, gene expressions of Apolipoprotein A-I and Apolipoprotein A-II were measured in this study.

Ethics code: IR.SSRI.REC. 1396, 134.

Findings: The findings of this study showed an increase in the gene expressions of Apolipoprotein A-I in the high-intensity interval $(\mathrm{P}=0.034)$ and continuous submaximal training groups $(\mathrm{P}=0.047)$, compared to the control group. Moreover, the results of the Bonferroni post-hoc test showed that there was no difference between high-intensity interval and continuous submaximal training groups $(\mathrm{P}=0.9)$. In addition, the results of this study showed that there was no significant difference among the three groups in terms of the gene expression of Apolipoprotein A-II.

Discussion \& Conclusions: High-intensity interval and continuous submaximal training can play important roles in reducing cardiovascular disease risks, such as atherosclerosis. This is done by increasing hepatic gene expression of Apolipoprotein A-I and the main factor taking cholesterol from the liver and ultimately the high-density lipoprotein receptor.

Keywords: Apolipoprotein A-I, Apolipoprotein A-II, Continuous submaximal training, High-intensity interval training

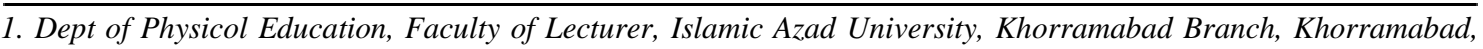
Iran

2. Dept of Nursing, Faculty of Nursing and Midwifery, Lorestan University of Medical Sciences, Khorramabad, Iran 3. Dept of Exercise Physiology, Faculty of Physicol Education, University of Buali Sina, Hamedan, Iran

* Corresponding author Email: Hasanvand121@gmail.com
}

Scientific Journal of Ilam University of Medical Sciences 